\title{
The Effectiveness of Course Review Horay Cooperative Learning Model for Elementary School Students
}

\author{
Paramananda Hutomo Putri, Aminuddin Kasdi \& Wahyu Sukartiningsih \\ State University of Surabaya \\ Surabaya, Indonesia \\ paramanandahp@gmail.com
}

\begin{abstract}
This study aims at evaluating the effectiveness of review horay cooperative learning model with power point media to improve critical thinking skills and student activities. The research used evaluation sheet and observation sheet. The participants were $\mathbf{5 0}$ fourth grade elementary school students in Sidodadi Elementary School, Surabaya, who were divided into two classes. This study found that Course Review Horay with power point media was effective in two parameters. The first parameter was the student activity which showed that the students were actively involved during the learning activities. The second parameter was the critical thinking skills which explained that all the phases in the Course Review Horay model with power point were at a very good level. Their dominant activities were solving problems, discussing, and collaborating. The finding of the evaluation of this model and media had been effectively applied in elementary schools.
\end{abstract}

\section{Keyword--Course Review Horay; Elementary Students}

\section{INTRODUCTION}

Currently, the curriculum used by Indonesia is the 2013 Curriculum. This is a curriculum that prioritizes students' understanding, skills and education. This curriculum requires students to understand the material, be active in the process of discussion and presentation, and have a polite attitude and high discipline. Social studies is one of the subjects found in the theme network of 2013 curriculum. Through social studies, students are directed to become democratic and responsible Indonesian citizens, as well as citizens who love peace [1]. One of the materials in social studies learning in elementary schools is the struggle of the heroes during the reign of Hindu, Buddhist and Islamic kingdoms. Alfian (2011) explained that current lessons related to history are considered boring. History is considered a subject that is not interesting, boring, difficult, and others that show students actually do not like the lesson. This can occur due to several factors, one of which is a monotonous learning method. According to the results of a poll conducted by Kompas Research and Development, $52 \%$ of respondents said the biggest obstacle in history learning was a combination of conventional, unattractive learning methods and unskilled teachers / educators in explaining history in an uninteresting way.
Today's development is rapid that it requires every student to have critical thinking. Students have to be good at filtering various information obtained so as not to be eroded by the times. Critical thinking is the process of systematic thinking in finding truth and building confidence in something that is factually and realistically studied and examined. Social studies is one subject that requires students to think critically. Critical thinking skills are useful to bring up the understanding built by students that the cognitive aspects will be better and it will also provide more understanding through the delivery.

According to [2], a learning will be more meaningful if the students are given the opportunity to participate in various activities or learning activities in which the students are able to actualize their abilities inside and outside the classroom. Learning activity is very important for students, because it provides opportunities for students to be actively involved in learning activities to support the success of the teaching and learning process and get benefit from these activities. Thus, the process of knowledge construction that occurs will be better.

Basically, the teacher plays an important role in the learning process. The role of the teacher is as a learning resource, manager, demonstrator, mentor and evaluator. Teachers do not only provide knowledge directly to students, but also guide students to know the concept of knowledge that will be received, then direct the discussion of the knowledge [3]. To bring up effective, efficient, and fun learning process in elementary school, teachers are expected to be innovative that they can help students in thinking and understanding the material. Teachers should think of ways that students can focus on the learning process that has taken place. The components playing as supporting factors in the learning process are: media, methods, strategies, approaches, and learning models.

Based on the observations that have been performed in class IV of Sidodadi Elementary school II /154 Surabaya, especially in social studies subjects, the teachers still seem unable to maximize the strategy in delivering the learning that students' critical thinking skills are not optimal and the learning process do not involve all students in the learning activities. The learning method used was not interesting and fun. It was 
because the teachers tend to prefer the method of the teaching using the lecture method by occasionally giving questions to students. Therefore, the learning in the classroom was still teacher-centered.

Cooperative learning is a learning approach that provides opportunities for students to act as teachers and provide explanations to their friends about certain subject matter [4]. The application of course review horay cooperative learning model is one example of a learning model that can be used as an alternative model in learning activities. The learning model is one of the cooperative learning models to create a pleasant atmosphere for students to take part in lessons. Furthermore, it can help students to grow their critical thinking and improve students' learning activities.

A series of studies have found a respectful correlation between student activity and cooperative learning approaches [5]. Students, who learn with active learning methods, do not only learn better, but also take more pleasure from the learning experience. One of the main methods for activating students into the classroom learning and providing a list of discussions, is the exchange of views, questions and answers [6]. In particular, cooperative learning has been reported to improve the students' learning [7]

The nature of cooperative learning is learning by doing and describing [8]. Cooperative learning is the work of students in small groups which help each other in the learning process. [9] In cooperative learning situations, the concepts taught are often described. The elaboration of learning concepts that consistently gives students who receive explanation or those who provide explanations with a deeper understanding and more complete retention than the concepts learned for a longer period of time [10]. In cooperative situations, the students obtain greater knowledge when they offer more explanation and elaboration to others [11]

In learning course review horay, students are divided into small groups, each of which consists of 4-5 people. Each group need to have a group symbol. Then, the teacher made 16 boxes and filled in the number in which one group chooses the box number which questions the number and answers the questions read by the teacher. If the answer from the group is correct, then the box is given the symbol or symbol of the group. It continues until the group symbols are formed vertically, horizontally, or diagonally. The groups that have got vertical, horizontal, or diagonal symbols have to shout hurray or other yells [12]. Each group member achieves his goal only if all the other members achieve their own learning goals.

[13] states that the course review horay model has several advantages including (a) its attractive structure and it can encourage students to be able to deepen the material in it; (b) a model that is not monotonous because it is interspersed with entertainment, thus, the atmosphere is not tense; (c) the spirit of learning increases because the atmosphere of learning takes place pleasantly; and (d) cooperation skill among students increasingly strains.
The implementation of a course review horay model is a good idea if it is supported by learning media. The learning media is intended to help arising students' interest in learning which, in turn, will gave an impact on understanding of the material. The learning media used to support this research was powerpoint media. Powerpoint is a Microsoft development program (software) that can be used as a tool to present material to the audiences, including in the learning process at school. This program, in addition to presentation, also provides various facilities for creating, processing, and audio and visual files. Several things that make the powerpoint interesting to be used as presentation tools are various text processing capabilities, colors, images, and animations that can be processed by themselves according to the creativity of the users.

The reasons for choosing powerpoint media as a learning medium was to optimize students' understanding including: (1) attract more students' attention (2) very easy to operate, (3) easy to reproduce or duplicate, (4) very practical so that it can be used at home or anywhere if there is a computer device.

Based on the discussion above, the researcher will evaluate the application of the Cooperative Learning Model of Course Review Horay for Elementary school students was based on two parameters, namely, student activity and critical thinking skills.

\section{METHOD}

This research used Quasi-Experimental Design in which such experimental research involved two groups, namely experimental class and control class. The control group was a group that was not influenced by certain variables or did not get a certain treatment, while the experimental group was a group that was influenced by certain variables or received certain treatment. The experimental group received cooperative learning treatment and the course review horay was assisted with powerpoint media, while the control class is the comparison of the changes that occurred in the experimental group. The syntax of the learning model consists of six phases; phase 1: clarifying goals, phase 2: explanation of information, phase 3: arranging students in teams, phase 4: guiding teams for learning, phase 5: evaluation, and phase 6: providing prizes.

The research subjects in this study were the fourth-grade students of SDN Sidodadi II / 154 Surabaya which were divided into two classes, $\mathrm{A}$ and $\mathrm{B}$, each of which consisted of 50 students. The location of this study was SDN Sidodadi II / 154 Surabaya, located at Jalan Srengganan Lebar No.8 Surabaya. The sampling was carried out using simple random sampling technique where members of sample from the population was taken randomly without paying attention to the strata in the population [14] The research design used was Non-equivalent Control Group Design in which the experimental group and the control group were not randomly selected (Sugiyono, 2012: 116).

\begin{tabular}{|c|c|c|}
\multicolumn{2}{c}{ TABLE I. } & RESEARCH DESIGN \\
\hline Pretest & Treatment & Posttest \\
\hline O1 & $X$ & O2 \\
\hline O3 & - & O4 \\
\hline
\end{tabular}


Where :

O1: experimental group pre-test

O3: control group pre-test

O2: experimental group post-test

O4: control group post-test

The instruments used in this study were explained as follows: 1. Evaluation sheet, 2. Observation sheet. The evaluation sheet used was in the form of a written test of the material related to the struggle of the heroes. The test was in the form of open questions in the form of descriptions, so that students could explore their abilities in critical thinking. The observation sheets were used to determine the activities of students in classroom learning, both for the control group (using conventional models) and the experimental group. The analysis of the data processing in this study used quantitative analysis techniques with statistical formulas and qualitative analysis descriptions.

III. RESUltS AND DiSCUSSION

TABLE II. VALIDATION OF COURSE REVIEW HORAY COOPERATIVE LEARNING MODEL WITH POWERPOINT MEDIA

\begin{tabular}{|c|c|c|c|}
\hline No & Experts & Percentage & Category \\
\hline 1 & Expert 1 & $88,9 \%$ & $\begin{array}{c}\text { Can be used with a little } \\
\text { revision }\end{array}$ \\
\hline 2 & Expert 2 & $91,4 \%$ & $\begin{array}{c}\text { Can be used with a little } \\
\text { revision }\end{array}$ \\
\hline
\end{tabular}

The table data above shows that this learning model was feasible to be used because the results of the assessment of the experts indicated that this model and media could be used with a little revision.

There are ten observation indicators in the observation sheet, each of which had four descriptors. Thus, the maximum score was 40 and the minimum score was 0 if no descriptors were visible during the treatment. The student activity score criteria used were "very high, high, medium, low, and very low".

\begin{tabular}{|c|c|c|c|c|c|c|c|}
\hline \multirow{3}{*}{ No } & \multirow{3}{*}{$\begin{array}{l}\text { TABLE III. } \\
\text { Indicator }\end{array}$} & \multicolumn{6}{|c|}{ STUDENT RESPONSES } \\
\hline & & \multicolumn{3}{|c|}{ Experimental class } & \multicolumn{3}{|c|}{ Control class } \\
\hline & & $\mathbf{I}$ & II & III & I & II & III \\
\hline 1. & Self-preparation & 3 & 4 & 4 & 4 & 4 & 4 \\
\hline 2. & $\begin{array}{l}\text { Respond } \\
\text { apperception }\end{array}$ & 3 & 3 & 4 & 2 & 3 & 4 \\
\hline 3. & $\begin{array}{l}\text { Pay attention to the } \\
\text { teacher's explanation }\end{array}$ & 3 & 2 & 4 & 2 & 3 & 2 \\
\hline 4. & $\begin{array}{l}\text { Do questions and } \\
\text { answering activities }\end{array}$ & 3 & 3 & 3 & 0 & 4 & 3 \\
\hline 5. & $\begin{array}{l}\text { Order in group } \\
\text { formation }\end{array}$ & 4 & 3 & 4 & 0 & 0 & 0 \\
\hline 6 & $\begin{array}{l}\text { Work on the problem } \\
\text { by collaborating with } \\
\text { the group }\end{array}$ & 1 & 2 & 3 & 0 & 0 & 0 \\
\hline 7. & Answer group quizzes & 3 & 2 & 3 & 4 & 2 & 3 \\
\hline 8. & Reflect & 1 & 3 & 3 & 2 & 2 & 3 \\
\hline 9. & Make conclusions & 0 & 1 & 2 & 2 & 2 & 2 \\
\hline 10. & $\begin{array}{l}\text { respond to the award } \\
\text { given by the teacher }\end{array}$ & 2 & 4 & 4 & 2 & 3 & 4 \\
\hline \multicolumn{2}{|c|}{ Total } & 23 & 27 & 34 & 18 & 22 & 25 \\
\hline \multicolumn{2}{|c|}{ Percentage (\%) } & 57,5 & 67,5 & 85 & 45 & 55 & 62,5 \\
\hline \multicolumn{2}{|c|}{ Criteria } & $\begin{array}{l}\text { medi } \\
\text { um }\end{array}$ & high & $\begin{array}{l}V e \\
r y\end{array}$ & $\begin{array}{l}\text { me } \\
\text { di }\end{array}$ & $\begin{array}{l}\text { me } \\
\text { di }\end{array}$ & high \\
\hline
\end{tabular}

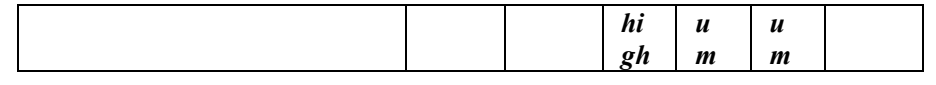

The data above shows that the activity of students in the experimental class and the control class both increased, but the activities of students in the experimental class were better than the activities of students in the control class.

The results of critical thinking skills show that Course Review Horay cooperative learning model with Power point influenced students' critical thinking skills between the control class and the experimental class with the following average values.

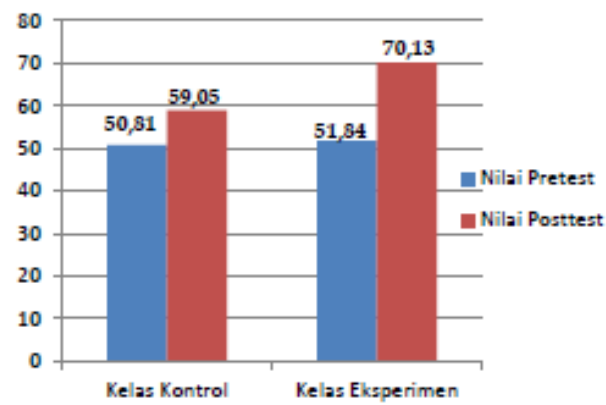

Fig. 1. Comparison of the average of pretest and posttest scores.

The table above shows that there was an increase in the average pretest and posttest scores in both the control and experimental classes. In the control class the average score of pretest was 50.81 and the average posttest score was 59.05. Meanwhile, in the experimental class, the average score of the pretest was 51.84 and the average posttest score was 70.13.

The results of students' critical thinking skills were obtained through the provision of test questions to students at the end of learning with the material struggle of the heroes during the reign of Hindu, Buddhist and Islamic kingdoms by containing five indicators of critical thinking skills.

The first indicator was the ability to analyze the questions carefully. In this indicator, students were asked to understand the main questions given by answering questions accurately and carefully where students were faced with questions about the roles of heroes of the heroes during the reign of Hindu, Buddhist and Islamic kingdoms.

The second indicator was the use of facts precisely and honestly. Students were asked to reveal facts related to the events of the reign of Hindu, Buddhist and Islamic kingdoms. The students were asked to reveal facts including characters, places, time and flow of events to be correctly said that it was able to use facts correctly and honestly.

The third indicator was to organize thoughts and express them clearly, logically or sensibly. In this indicator, the students were asked to organize and express clearly and sensibly dealing with the roles of heroes in governing the Hindu, Buddhist and Islamic kingdoms.

The fourth indicator was to deny the irrelevant arguments and submit the relevant arguments. In this indicator, the students were faced with arguments that students needed to 
understand and students were asked to agree whether or not they agreed and they were accompanied by reasons.

The fifth or last indicator was to form a valid conclusion. The students were asked to draw conclusions from the material taught. The students were faced with questions that asked them to make conclusions about attitudes that could be taken from the hero figures during the reign of Hindu, Buddhist, and Islamic kingdoms.

The influence of the cooperative model type of course review horay assisted by powerpoint media on increasing learning activities and critical thinking skills of students could be seen from the results of student learning outcomes. The results of the pretest and posttest were tested by t-test to determine the effect of the application of this cooperative models on the improvement of learning activities and students' critical thinking skills. Before the t-test was carried out, the researcher was tested in terms of the normality and the homogeneity test to find out whether the data was normally distributed. Here is the normality test result.

TABLE IV. NORMALITY TEST RESULT

\begin{tabular}{|c|c|c|c|c|c|c|c|}
\hline \multicolumn{8}{|c|}{ Tests of Normality } \\
\hline & \multirow[b]{2}{*}{ Kelas } & \multicolumn{3}{|c|}{$\begin{array}{c}\text { Kolmogorov- } \\
\text { Smirnov }^{2}\end{array}$} & \multicolumn{3}{|c|}{ Shapiro-Wilk } \\
\hline & & Statistic & Df & Sig. & Statistic & Df & Sig. \\
\hline \multirow[t]{2}{*}{ Pretest } & Kontrol &, 133 & 37 &, 097 & ,958 & 37 & 181 \\
\hline & Eksperimen & , 141 & 38 &, 056 & 959 & 38 &, 175 \\
\hline \multicolumn{8}{|c|}{ Tests of Normality } \\
\hline & & \multicolumn{3}{|c|}{$\begin{array}{c}\text { Kolmogorov- } \\
\text { Smirnov }^{a}\end{array}$} & \multicolumn{3}{|c|}{ Shapiro-Wilk } \\
\hline & Kelas & Statistic & Df & Sig. & Statistic & Df & Sig. \\
\hline \multirow[t]{2}{*}{ Posttest } & Kontrol &, 124 & 37 &, 165 & 964 & 37 & 278 \\
\hline & Eksperimen &, 130 & 38 &, 102 & ,939 & 38 & .038 \\
\hline
\end{tabular}

Based on the results of calculations in the KolmogorovSmornov table, the significance value on the results of the pretest of the control class was $0.097>0.05$, then the data from the pretest was stated to be normally distributed. The experimental class obtained the significance value of the pretest $0.056>0.05$, the data from the pretest were normally distributed.

Based on the calculation on the Kolmogorov-Smirnov table the posttest results data in the control class and experimental class were normally distributed. It was indicated by the significance value on the posttest results of the control class of $0.165>0.05$ and in the experimental class the significance value of the posttest was $0.102>0,05$.

After the normality test was done, the next step was to do a homogeneity test with the aim of knowing whether the two classes were homogeneous or not. The followings are the results of the pretest and posttest homogeneity test:

TABLE V. Homogeneity TeSt Result

\begin{tabular}{|c|c|c|c|}
\hline \multicolumn{4}{|c|}{ Test of Homogeneity of Variances } \\
\hline \multicolumn{4}{|l|}{ pretest } \\
\hline Levene Statistic & df1 & $\mathrm{df} 2$ & Sig. \\
\hline, 065 & 1 & 73 & ,799 \\
\hline \multicolumn{4}{|c|}{ Test of Homogeneity of Variances } \\
\hline \multicolumn{4}{|l|}{ posttest } \\
\hline Levene Statistic & df1 & df2 & Sig. \\
\hline .047 & 1 & 73 & .828 \\
\hline
\end{tabular}

The homogeneity testing in this study was carried out using SPSS version 22 through the Levene Test test. According to the test criteria, if the significance number obtained $<0.05$, then the data was not homogeneous, if the significance number $>0.05$ then the data was homogeneous.

From the calculation results above, it can be seen the level of Sig. $>0.05(0.799>0.05)$. So, it can be concluded that the pretest data from the control class and the experimental class were homogeneous. Table 4.7 shows that the posttest data was homogeneous $(0.828>0.05)$, meaning that there was no variance between the experimental group and the control group. Therefore, the variances of the two groups were the same.

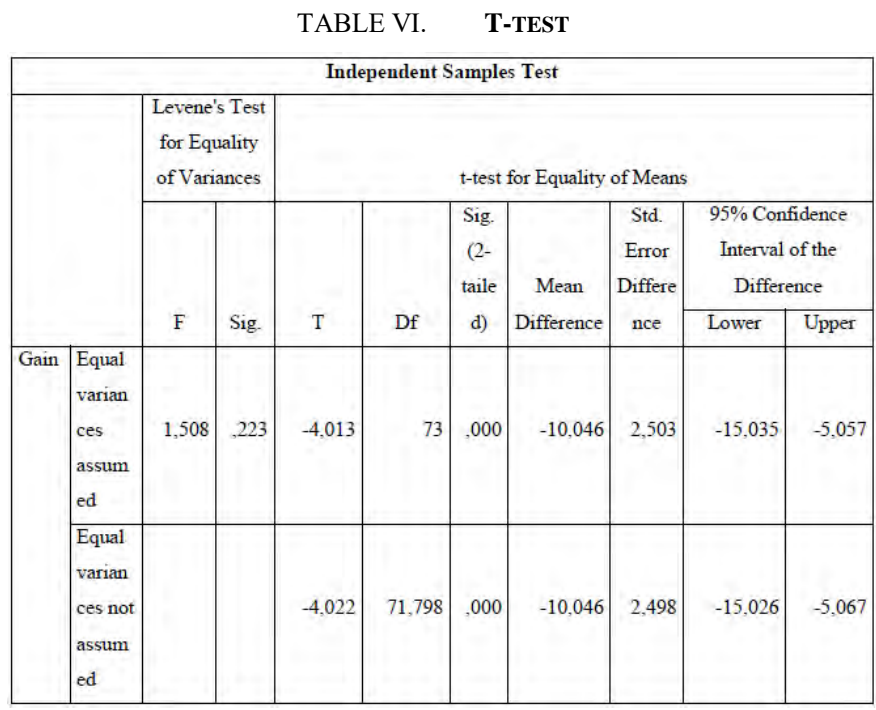

There were two ways to see whether or not there was an influence of the cooperative model type horay course review. First, it was done by comparing $t$ count with $t$ table. If at a significance level of $0.05 \mathrm{t}$-count value $<\mathrm{t}$ table, then Ho was rejected. On the contrary, if the - $t$-count value $>t$ table, then Ho was accepted. The value of $t$ table could be seen in the statistical table at a significance of 0.05: 2 (two-sided test) with degrees of freedom (Df) $=n-2$ or $75-2=73$, obtained t table-1.993. From the results of the calculation above, it was known that $t$ count was $4.013<\mathrm{t}$ table $(-1.993)$ at a significance level of 0.025 , so it could be concluded that Ho was rejected.

The second way was to look at the Sig. (2-tailed). If the pvalue was in the Sig. (2-tailed) $<0.05$, then Ho was rejected. Based on the table above, it was obtained sig (2-tailed) of 0,000 $<0,05$, so Ho was rejected. It can be concluded that there was a significant influence on the use of cooperative models of course review horay types with power point media on the students' critical thinking skills. 


\section{CONCLUSION}

Cooperative model of course review horay with power point media had a significant effect on the student learning activities in social studies class of fourth grade at SDN Sidodadi II / 154 Surabaya related to the struggle of the heroes during the reign of Hindu, Buddhist and Islamic kingdoms materials. It was supported by the results of observations of researchers when the learning took place showing differences in student activities in the experimental class and control class.

In relation to the critical thinking skills, there was a significant influence from the model on critical thinking skills in the material of the struggle of the heroes during the reign of Hindu, Buddhist and Islamic kingdoms. It was proven by the results of the t-test-count $<$-table of $-4.013<$ t table $(-1.993)$ and in the column Sig. ( 2 tailed) $0.000<0.05$ which indicated a significant influence on the implementation of the cooperative model towards the students' critical thinking skills.

\section{REFERENCES}

[1] I. K. Ahmadi and S. Amri, "Metode Pembelajaran IPS Terpadu." Jakarta: Prestasi Pustaka, 2011.

[2] D. K. Rusman and C. Riyana, "Pembelajaran Berbasis Teknologi Informasi dan Komunikasi," Bandung Rajawali Pers, 2011.

[3] W. Sanjaya, "Strategi pembelajaran berorientasi standar proses pendidikan." Jakarta: kencana, 2006.

[4] R. Leikin and O. Zaslavsky, "Cooperative learning in mathematics,"
Math. Teach., vol. 92, no. 3, p. 240, 1999.

[5] D. W. Johnson and R. T. Johnson, "New developments in social interdependence theory," Genet. Soc. Gen. Psychol. Monogr., vol. 131, no. 4, pp. 285-358, 2005.

[6] E. Payne and L. Whittaker, Developing essential study skills. Pearson Education, 2006.

[7] L. L. Beck and A. W. Chizhik, "An experimental study of cooperative learning in CS1," in ACM SIGCSE Bulletin, 2008, vol. 40, no. 1, pp. 205209.

[8] T. Liang, "Implementing cooperative learning in EFL teaching: Process and effects (Doctoral dissertation, National Taiwan Normal University).[Online] Available: http://www. asian-efl-journal. com," Thesis_Liang_Tsailing.pdf(July 17, 2009), 2002.

[9] K. U. Acikgoz, "Aktif ogrenme [Active learning]," Izmir, Turkey Egit. Dunya. Yayinlari, 2005.

[10] M. M. Chianson, M. S. Kurumeh, and J. A. Obida, "Effect of cooperative learning strategy on students' retention in circle geometry in secondary schools in Benue State, Nigeria," Am. J. Sci. Ind. Res., vol. 2, no. 1, pp. 33-36, 2010

[11]E. Zakaria, L. C. Chin, and M. Y. Daud, "The effects of cooperative learning on students' mathematics achievement and attitude towards mathematics," J. Soc. Sci., vol. 6, no. 2, pp. 272-275, 2010.

[12]A. Suprijono, Cooperative learning: teori \& aplikasi PAIKEM. Pustaka Pelajar, 2009.

[13] M. Huda, "Model-Model Pengajaran dan Pembelajaran: Isu-Isu Metodis dan Paradigmatis: Pustaka Pelajar," 2014.

[14] Sugiyono, Metode penelitian pendidikan:(pendekatan kuantitatif, kualitatif dan $R \& D$ ). Alfabeta, 2008 